\title{
АНАЛІЗ СУТНОСТІ ПОНЯТТЯ ЕКОНОМІЧНОЇ БЕЗПЕКИ ПІДПРИЕМСТВА
}

\section{Лисенко А.О., канд. екон. наук, доцент}

Харківський національний автомобільно-дорожній університет

Грабар Д.О., студент

\section{Харківський національний автомобільно-дорожній університет}

Постановка проблеми. Економічна безпека підприємства $є$ однією із найважливіших і найнеобхідніших умов успішного функціонування фірми в сучасних нестабільних умовах. Сучасні суб`єкти господарювання змушені пристосовуватись до навколишніх умов і шукати раціональні та найбільш адекватні шляхи для мінімізації загроз своєму функціонуванню. Для того, щоб підприємство залишалось «на плаву» необхідно вирішити ряд проблем, які знижують ефективність діяльності кожної фірми, серед яких: брак фінансових ресурсів, знос основних фондів, старіння технологічної бази, недостатній рівень кваліфікації персоналу, а також криміналізація суспільства й економіки.

Аналіз останніх досліджень і публікацій. Забезпечення економічної безпеки підприємств є гарантом державної незалежності України, умовою іiі сталого розвитку та зростання добробуту громадян, тому питанню забезпечення економічної безпеки суб єктів господарювання України приділяється достатня увага вченими, серед яких можна відзначити таких науковців як 3. Варналій, Д. Гордієнко, А. Кальман, Г. Дарнопих, В. Ліпкан, А. Торкунов, А. Бакунов, С. Григорук, Г. Дем'яненко, Г. Козаченко, Т. Логутова, О. Ляшенко, Д. Нагаєвський, В. Пономарьов, А. Сергєєва, О. Хомів, Д. Шалагін, Л. Шемаєва, О. Юсипович та ін.

Невирішені складові загальної проблеми. Незважаючи на існування значної кількості наукових публікацій 3 цього питання, науковий апарат управління економічною безпекою ще не є остаточно сформованим і потребує подальшого дослідження.

Формулювання цілей статті. Метою дослідження є розкриття сутності поняття «економічна безпека підприємства» 3 точки зору різних науковців та аналіз зазначеної категорії.

Виклад основного матеріалу дослідження. Безпека як певний стан, що характеризується відсутністю загроз, є предметом дослідження багатьох галузей економічних, соціальних, природничих, технічних, медичних i суспільних наук. Категорія безпеки формує багато науково-практичних завдань iз різних сфер господарської діяльності та щоденного життя. Перші публікації, у яких зроблено спробу виокремити науку про проблеми безпеки як окрему дисципліну, з'явились у 1989 р. і це було спричинено появою нових потреб та очікувань, а також новими ринковими умовами, що формувалися в Європі. Таким чином, безпеку можна визначити як певний об'єктивний стан, заснований на відсутності загрози. Під безпекою розуміють також стан без 
загроз, стан спокою, впевненості, опори в іншому суб'єкті або «протилежність загрози», визначають загрозу як потенційну причину небажаного стану. Загроза не може бути окремою категорією, оскільки загроза завжди притаманна певному суб'єкту, по відношенню до якого вона має дестабілізуючий, деструктивний характер. Загроза є причиною можливої появи негативних наслідків, характер яких визначається рівнем слабких зон суб'єкта, його захищеністю від впливу факторів зовнішнього та внутрішнього середовища. Джерелами виникнення загроз $є$ певні умови, які знаходяться як у самому суб'єкті, якого вони стосуються, так в його оточенні та у зв'язках суб'єкта 3 оточенням [1;2]. На первісних етапах розгляду економічної безпеки з науковопрактичної точки зору їй передував «захисний» погляд на економічну безпеку. Тобто спочатку обирався певний шлях i вектор розвитку діяльності підприємства, котрий характеризувався певними загрозами, які підприємство, щоб досягти поставлених цілей, змушено було уникати, здебільшого за фактом настання. Для цієї концепції характерне реактивне управління соціальноекономічною безпекою підприємства, тобто за фактом настання необхідності.

Оскільки безпека як об’єкт наукового дослідження має багатоаспектний характер (як власне і соціально-економічна безпека підприємства), то має місце перетинання багатьох наукових галузей і теорій щодо управління безпекою. На сьогоднішній день категорія «безпека» набуває більшої вживаності в усіх сферах життя, зокрема в сфері управління підприємством [1;2].

Поняття «економічна безпека» мало багато тлумачень 3 огляду на зміну навколишніх умов життедіяльності кожного суб єкта господарювання. Вчені розробляли різні підходи стосовно виявлення сутності цієї категорії. Кожен науковець при розкритті даного поняття акцентував увагу на певній особливості. Найбільш популярні дефініції розглянуті в табл. 1.

Таблиия 1

\section{Система визначень поняття «економічна безпека підприсмства»}

з точки зору різних вчених

\begin{tabular}{|l|l|}
\hline \multicolumn{1}{|c|}{ Автор } & \multicolumn{1}{|c|}{ Визначення поняття «економічна безпека підприємства (ЕБП)» } \\
\hline \multicolumn{1}{|c|}{ С } & \multicolumn{1}{|c|}{2} \\
\hline $\begin{array}{l}\text { С. Олейніков } \\
\text { [3, с. 138] }\end{array}$ & $\begin{array}{l}\text { стан найбільшективного використання ресурсів } \\
\text { подолання загроз і забезпечення стабільного функціонування } \\
\text { підприємства тепер, і в майбутньому. }\end{array}$ \\
\hline $\begin{array}{l}\text { С. Ілляшенко [4], } \\
\text { Т. Кузенко [5, с. 12] }\end{array}$ & $\begin{array}{l}\text { стан ефективного використання його ресурсів і існуючих ринкових } \\
\text { можливостей, що дозволяє запобігати внутрішнім і зовнішнім } \\
\text { загрозам, і забезпечувати його тривале виживання та стійкий розвиток } \\
\text { на ринку відповідно до обраної місії. }\end{array}$ \\
\hline А. Кірієнко [6, с. 6] & $\begin{array}{l}\text { стан оптимального для підприємства рівня використання його } \\
\text { економічного потенціалу, за якого діючі та/або можливі збитки } \\
\text { виявляються нижчими за встановлені підприємством межі. }\end{array}$ \\
\hline
\end{tabular}




\begin{tabular}{|c|c|}
\hline \multicolumn{2}{|r|}{ Продовження таблии̧і 1} \\
\hline 1 & 2 \\
\hline \multicolumn{2}{|r|}{ Стан виробничої системи } \\
\hline В. Тамбовцев [7] & $\begin{array}{l}\text { сукупність властивостей стану виробничої підсистеми економічної } \\
\text { системи, яка забезпечує можливість досягнення цілей всієї системи. }\end{array}$ \\
\hline Ю. Лисенко [8] & $\begin{array}{l}\text { стан виробничо-економічної системи, при якому функціонують } \\
\text { механізми запобігання чи зменшення ступеня впливу загроз } \\
\text { стабільності функціонування і розвитку підприємства. }\end{array}$ \\
\hline О. Судакова [9] & $\begin{array}{l}\text { такий стан розвитку економічної системи, який забезпечує ії } \\
\text { ефективне функціонування засобом належного використання } \\
\text { внутрішніх і зовнішніх чинників, а також здатність результативного } \\
\text { протистояння негативному зовнішньому впливу. }\end{array}$ \\
\hline \multicolumn{2}{|r|}{ Наявність конкурентних переваг } \\
\hline В. Бєлокуров [10] & $\begin{array}{l}\text { наявність конкурентних переваг, зумовлених відповідністю } \\
\text { матеріального, фінансового, кадрового, техніко-технологічного } \\
\text { потенціалів i організаційної структури підприємства його } \\
\text { стратегічним цілям і завданням. }\end{array}$ \\
\hline \multicolumn{2}{|r|}{ Стан економічного розвитку } \\
\hline Р. Дацків [11] & $\begin{array}{l}\text { такий стан економічного розвитку суб’єктів господарювання (особи, } \\
\text { держави, організації), який забезпечує йому гармонійний розвиток, } \\
\text { ефективне використання шансів i усунення загроз оточуючого } \\
\text { середовища. }\end{array}$ \\
\hline \multicolumn{2}{|r|}{ Гармонізація економічних інтересів } \\
\hline $\begin{array}{l}\text { Г. Козаченко, } \\
\text { В. Пономарьов, } \\
\text { О. Ляшенко [12, с. } 87]\end{array}$ & $\begin{array}{l}\text { міра гармонізації в часі й просторі економічних інтересів } \\
\text { підприємства з інтересами пов'язаних } 3 \text { ним суб'єктів навколишнього } \\
\text { середовища, які діють поза межами підприємства. }\end{array}$ \\
\hline
\end{tabular}

У табл. 2 наведено та проаналізовано визначення наукового поняття «ЕБП»

Таблиця 2

Аналіз визначень наукового поняття «ЕБП»

\begin{tabular}{|c|c|}
\hline Тлумачення поняття як & Аналіз визначень \\
\hline 1 & 2 \\
\hline $\begin{array}{l}\text { Стан ефективного } \\
\text { використання ресурсів } \\
\text { (С. Олейніков, } \\
\text { С. Ілляшенко, } \\
\text { Т. Кузенко, } \\
\text { А. Кірієнко) }\end{array}$ & $\begin{array}{l}\text { Зазначені вчені намагалися уникнути факт зовнішнього } \\
\text { негативного впливу на підприємство різних факторів, тобто } \\
\text { загроз, які стримують ефективний розвиток фірми. Тут увага } \\
\text { приділяється більше внутрішньому ресурсному потенціалу, } \\
\text { раціональне використання якого може забезпечити стабільний } \\
\text { розвиток та запобігання загрозам. }\end{array}$ \\
\hline $\begin{array}{l}\text { Стан виробничої системи } \\
\text { (В. Тамбовцев, } \\
\text { Ю. Лисенко, } \\
\text { О. Судакова) }\end{array}$ & $\begin{array}{l}\text { ЕБП розглядається як певний стан функціонування } \\
\text { підприємства, при якому досягається протистояння зовнішнім } \\
\text { чинникам і створення таких внутрішніх умов, при яких } \\
\text { стабільність роботи підприємства є непохитною. }\end{array}$ \\
\hline $\begin{array}{l}\text { Наявність конкурентних } \\
\text { переваг } \\
\text { (В. Бєлокуров) }\end{array}$ & $\begin{array}{l}\text { Прихильник цього підходу вважає, що наявність конкурентних } \\
\text { переваг є ключовим аспектом безпеки фірми. Належний } \\
\text { матеріальний рівень, фінансовий, кадровий, техніко- } \\
\text { технологічний потенціали та організаційна структура } \\
\text { підприємства забезпечують захист від несприятливих обставин } \\
\text { ззовні та досягнення поставлених цілей. }\end{array}$ \\
\hline
\end{tabular}


Продовження таблииі 2

\begin{tabular}{|c|c|}
\hline 1 & 2 \\
\hline $\begin{array}{l}\text { Стан економічного } \\
\text { розвитку } \\
\text { (Р. Дацків) }\end{array}$ & $\begin{array}{l}\text { Передбачається, що ЕБП буде досягнута при піднятті } \\
\text { економічного розвитку підприємства на такий належний рівень, } \\
\text { при якому усунення загроз і гармонійний розвиток не буде } \\
\text { важким. }\end{array}$ \\
\hline $\begin{array}{l}\text { Гармонізація } \\
\text { економічних інтересів } \\
\text { (Г. Козаченко, } \\
\text { В. Пономарьов, } \\
\text { О. Ляшенко) }\end{array}$ & $\begin{array}{l}\text { Полягає в тому, щоб досягти співпадінню, гармонії та } \\
\text { аналогічності цілей і інтересів фірми та суб єктів зовнішнього } \\
\text { середовища, щоб не виникало протиріч між ними. }\end{array}$ \\
\hline
\end{tabular}

Отже, економічна безпека підприємства, з однієї сторони, представляє собою універсальну категорію, а $з$ іншої - до розкриття іiї сутності можна підійти 3 різних боків і тлумачити це визначення, опираючись на певну особливість бачення. Але єдиним аспектом, який об'єднує розглянуті визначення, $є$ саме мета ЕБП. Тому основними ії цілями можна виділити:

- забезпечення фінансової ефективності функціонування підприємства;

- максимальне використання технологічного потенціалу фірми і підвищення іiї конкурентоспроможності;

- досягнення ефективної організаційної структури та управління підприємством;

- забезпечення високого рівня кваліфікації кадрів;

- високий рівень екологічності підприємства, тобто мінімізація шкідливих викидів у навколишнє середовище;

- забезпечення надійності правового захисту функціонування підприємства;

- інформаційний захист.

Висновки 3 проведеного дослідження. Таким чином, стабільність і успішність функціонування підприємства, досягнення його стратегічних цілей, а також збільшення прибутку неможливе без належного рівня економічної безпеки. Багато вчених розглядають це визначення по-своєму, але метою кожного автора все ж таки залишається забезпечення стабільного, системного розвитку підприємства як в поточній, так і в довгостроковій перспективі.

\section{Перелік посилань}

1. Безбожний В. Л. Вибір способу забезпечення соціально-економічної безпеки великих промислових підприємств : дис. канд. екон. наук : 08.00 .04 / Економіка та управління підприємствами (за видами економічної діяльності). Луганськ, 2009. 224 с.

2. Ляшенко О. М. Концептуалізація управління економічною безпекою підприємства : монографія. Луганськ : СНУ ім. В. Даля, 2011. 400 с.

3. Основы экономической безопасности / Под. ред. Е. А. Олейникова. М.: 3АО «Бизнес-школа «Интел-Синтез», 1997. 288 с.

4. Ильяшенко С. И. Составляющие экономической безопасности предприятия и подходы к их оценке. Актуальні проблеми економіки. 2003. № 3 (21). C. 12-19. 
5. Кузенко Т. Б. Планування економічної безпеки підприємств в умовах ринкової економіки : дис. канд. екон. наук : 08.06.01. Європейський ун-т фінансів, інформаційних систем, менеджменту. К., 2003. 194 с.

6. Кірієнко А. В. Механізм досягнення і підтримки економічної безпеки підприємства : автореф. дис. на здобуття ступня канд. екон. наук : 08.06.01. К., 2000. 19 c.

7. Тамбовцев В. Объект экономической безопасности России. Bonpocbl экономики. 1994. № 12. С. 35-42.

8. Лысенко Ю. Г., Лопатовський В. Г. Механизмы управления экономической безопасностью. Поняття, класифікація ризиків та методи боротьби з ними. Вісник Технологічного університету Поділля. 2004. № 4. С. 177-180.

9. Судакова О. І., Гречко Д. В., Шкурупій А. В. Стратегія забезпечення належної економічної безпеки підприємства: сайт. URL: http://www.rusnauka.com/4._SVMN_2007/Economics/18818.doc.htm.

10. Белокуров В. В. Структура функциональных составляющих экономической безопасности предприятия: сайт. URL: http : // www.safetyfactor. ru -20.01 .2005 .

11. Дацків Р. М. Економічна безпека у глобальному вимірі. Актуальні проблеми економіки. 2004. № 7 (37). С. 143-153.

12. Козаченко Г. В., Пономарьов В. П., Ляшенко О. М. Економічна безпека підприємства: сутність та механізм забезпечення : монографія. К.: Лібра, 2003. 280 c.

\section{References}

1. Bezbozhnyi, V. (2009), "The choice of a way to ensure the socio-economic security of large industrial enterprises: diss. cand. econom. sciences: 08.00.04" [Vybir sposobu zabezpechennya sotsial'no-ekonomichnoyi bezpeky velykykh promyslovykh pidpryyemstv : dys. kand. ekon. nauk : 08.00.04], Lugansk, 224 p.

2. Lyashenko, O. (2011), "Conceptualization of management of economic security of the enterprise: a monograph" [Kontseptualizatsiya upravlinnya ekonomichnoyu bezpekoyu pidpryyemstva : monohrafiya], Luhans'k, $400 \mathrm{p}$.

3. Oleynikova, A. (1997), "Fundamentals of economic security" [Osnovy ekonomicheskoy bezopasnosti], Moscow, $288 \mathrm{p}$.

4. Il'yashenko, S. (2003), "Components of economic security of an enterprise and approaches to their assessment" [ Sostavlyayushchiye ekonomicheskoy bezopasnosti predpriyatiya $\mathrm{i}$ podkhody $\mathrm{k}$ ikh otsenke], Actual problems of the economy, No. 3 (21), P. 12-19.

5. Kuzenko, T. (2003), "Planning of economic security of enterprises in the conditions of market economy: dissertation cand. econom. sciences: 08.06.01" [Planuvannya ekonomichnoyi bezpeky pidpryyemstv $\mathrm{v}$ umovakh rynkovoyi ekonomiky : dys. kand. ekon. nauk : 08.06.01], Kiev, 194 p.

6. Kirienko, A. (2000), "The mechanism of achievement and maintenance of economic security of the enterprise: abstract. diss. for the candidate's foot econom. sciences: 08.06.01" [Mekhanizm dosyahnennya i pidtrymky ekonomichnoyi bezpeky 
pidpryyemstva : avtoref. dys. na zdobuttya stupnya kand. ekon. nauk : 08.06.01], Kiev, 19 p.

7. Tambovtsev, V. (1994), "Object of economic security of Russia" [Ob"yekt ekonomicheskoy bezopasnosti Rossii], Economic issues, No. 12, P. 35-42.

8. Lysenko, Y. U., Lopatovs'kyy, V. (2004), "Mechanisms for managing economic security. The concept, classification of risks and methods of dealing with them" [Mekhanyzmy upravlenyya ékonomycheskoy bezopasnost'yu. Ponyattya, klasyfikatsiya ryzykiv ta metody borot'by z nymy], Bulletin of the Podillia University of Technology, No. 4, P. 177-180.

9. Sudakova, O., Hrechko, D., Shkurupiy, A. "Strategy for ensuring proper economic security of the enterprise" [Stratehiya zabezpechennya nalezhnoyi ekonomichnoyi bezpeky pidpryyemstva], available at: http://www.rusnauka.com/4._SVMN_2007/Economics/18818.doc.htm.

10. Belokurov, V. "The structure of the functional components of the economic security of the enterprise" [Struktura funktsional'nykh sostavlyayushchikh ekonomicheskoy bezopasnosti predpriyatiya], available at: http : // www.safetyfactor.ru.

11. Datskiv, R. (2004), "Economic security in the global dimension" [Ekonomichna bezpeka u hlobal'nomu vymiri], Current problems of the economy, No. 7 (37), P. 143-153.

12. Kozachenko, H., Ponomar'ov, V., Lyashenko, O. (2003), "Economic security of the enterprise: essence and mechanism of providing: a monograph" [Ekonomichna bezpeka pidpryyemstva: sutnist' ta mekhanizm zabezpechennya : monohrafiya], Kiev, 280 p.

\section{РЕФЕРАТИ РЕФЕРАТЫ ABSTRACTS}

\section{УДК 338.47; JEL Classification: D21, D29}

\section{Лисенко А.О., Грабар Д.О. АНАЛІЗ СУТНОСТІ ПОНЯТТЯ} ЕКОНОМІЧНОЇ БЕЗПЕКИ ПІДПРИЕМСТВА

Mema. Метою дослідження є розкриття сутності поняття «економічна безпека підприємства» 3 точки зору різних науковців та аналіз зазначеної категорії. Методика дослідження. Для досягнення зазначеної мети, у роботі використано метод угруповання, який було застосовано при виявленні підходів до визначення сутності досліджуваного поняття «економічна безпека підприємства». Результати. У роботі досліджено систему визначень поняття «економічна безпека підприємства» 3 точки зору різних вчених, де саме поняття «економічна безпека підприємства» розглядається 3 таких напрямків як: стан ефективного використання ресурсів, стан виробничої системи, наявність конкурентних переваг, стан економічного розвитку, гармонізація економічних інтересів. Проведено аналіз визначень наукового поняття «економічна безпека підприємства», де зазначено, що, 3 однієї сторони, економічна безпека підприємства представляє собою універсальну категорію, а 3 іншої - до розкриття іï сутності можна підійти з різних боків і тлумачити це визначення, 
опираючись на певну особливість бачення. Стабільність і успішність функціонування підприємства, досягнення його стратегічних цілей, а також збільшення прибутку неможливе без належного рівня економічної безпеки. Економічна безпека підприємства $є$ визначною для економічної безпеки суспільства, особливо в сьогоденні, де світова криза диктує свої умови для виживання не тільки в Україні, а в більшості розвинених країн. Наукова новизна. У ході наукового дослідження було виділено такі основні цілі економічної безпеки підприємства: забезпечення фінансової ефективності функціонування підприємства, максимальне використання технологічного потенціалу фірми і підвищення іiі конкурентоспроможності, досягнення ефективної організаційної структури та управління підприємством, забезпечення високого рівня кваліфікації кадрів, високий рівень екологічності підприємства, тобто мінімізація шкідливих викидів у навколишнє середовище, забезпечення надійності правового захисту функціонування підприємства, інформаційний захист. Практична значущість. Сферою застосування результатів дослідження є будь-яка галузь, що сприяє економічному розвитку i функціонуванню держави на належному рівні.

Ключові слова: економічна безпека; безпека суспільства; підприємство; ресурси; ефективність функціонування.

\section{УДК 338.47; JEL Classification: D21, D29}

Лысенко А.А., Грабарь Д.А. АНАЛИЗ СУЩНОСТИ ПОНЯТИЯ ЭКОНОМИЧЕСКОЙ БЕЗОПАСНОСТИ ПРЕДПРИЯТИЯ

Цель. Целью исследования является раскрытие сущности понятия «экономическая безопасность предприятия» с точки зрения различных ученых и анализ указанной категории. Методика исследования. Для достижения указанной цели, в работе использован метод группировки, который был применен при выявлении подходов к определению сущности исследуемого понятия «экономическая безопасность предприятия». Результаты. В работе исследована система определения понятия «экономическая безопасность предприятия» с точки зрения различных ученых, где само понятие «экономическая безопасность предприятия» рассматривается по таким направлениям как: состояние эффективного использования ресурсов, состояние производственной системы, наличие конкурентных преимуществ, состояние экономического развития, гармонизация экономических интересов. Проведен анализ определений научного понятия «экономическая безопасность предприятия», где указано, что, с одной стороны, экономическая безопасность предприятия представляет собой универсальную категорию, а с другой - к раскрытию ее сущности можно подойти с разных сторон и толковать это определение, опираясь на определенную особенность видения. Стабильность и успешность функционирования предприятия, достижение его стратегических целей, а также увеличение прибыли невозможно без надлежащего уровня экономической безопасности. Экономическая безопасность предприятия является определяющей для экономической безопасности общества, особенно в 
настоящем, где мировой кризис диктует свои условия для выживания не только в Украине, а в большинстве развитых стран. Научная новизна. В ходе научного исследования были выделены следующие основные цели экономической безопасности предприятия: обеспечение финансовой эффективности функционирования предприятия, максимальное использование технологического потенциала фирмы и повышение ее конкурентоспособности, достижение эффективной организационной структуры и управления предприятием, обеспечение высокого уровня квалификации кадров, высокий уровень экологичности предприятия, то есть минимизация вредных выбросов в окружающую среду, обеспечение надежности правовой защиты функционирования предприятия, информационная защита. Практическая значимость. Сферой применения результатов исследования является любая отрасль, которая способствует экономическому развитию и функционированию государства на должном уровне.

Ключевые слова: экономическая безопасность; безопасность общества; предприятие; ресурсы; эффективность функционирования.

\section{UDC 338.47; JEL Classification: D21, D29}

\section{Lysenko A., Grabar D. ANALYSIS OF THE ESSENCE OF THE ECONOMIC SECURITY CONCEPT OF ENTERPRISE}

Purpose. The aim of the study is to disclose the essence of the concept of "economic security of the enterprise" from the point of view of various scientists and the analysis of this category. Methodology of research. To achieve this goal, the grouping method was used for identify the approaches to determining the essence of the studied concept of "economic security of the enterprise". Findings. The paper studies the system for determining the concept of "economic security of the enterprise" from the point of view of various scientists, where the concept of "economic security of the enterprise" is considered in such areas as: the state of the efficient use of resources, the state of the production system, the presence of competitive advantages, the state of the economic development, the harmonization of economic interests. The analysis of the definitions of the scientific concept of "economic security of an enterprise" is carried out, where it is indicated that, on the one hand, the economic security of an enterprise is a universal category, and on the other hand, it is possible to approach its essence from different directions and interpret this definition based on a specific feature of the vision. Stability and success of the enterprise, achieving its strategic goals, as well as increasing profits is impossible without an appropriate level of economic security. The economic security of the enterprise is crucial for the economic security of society, especially in the present, where the global crisis dictates its own conditions for survival not only in Ukraine, but in most developed countries. Originality. In the course of scientific research, the following main objectives of the economic security of the enterprise were identified: ensuring the financial efficiency of the functioning of the enterprise, maximizing the use of the technological potential of the company and raising its competitiveness, achieving an effective organizational structure and managing the 
enterprise, ensuring a high level of staff qualifications, a high level of environmental friendliness of the enterprise, i.e. minimization of harmful emissions into the environment, ensuring the reliability of legal protection of the functioning of the enterprise, information protection. Practical value. The scope of the research results is any industry that contributes to the economic development and functioning of the state at the proper level.

Key words: economic security; public safety; enterprise; resources; efficiency of the functioning.

\section{Відомості про авторів / Сведения об авторах / About the Authors}

Лисенко Аліна Олександрівна - кандидат економічних наук, доцент, Харківський національний автомобільно-дорожній університет, доцент кафедри економіки і підприємництва, м. Харків, Україна; e-mail: alina77775@ukr.net;. ORCID ID: https://orcid.org/0000-0001-9274-1831. Моб. 066-392-26-23.

Лысенко Алина Александровна - кандидат экономических наук, доцент, Харьковский национальный автомобильно-дорожный университет, доцент кафедры экономики и предпринимательства, г. Харьков, Украина.

Lysenko Alina - PhD in Economics, Associate Professor, Kharkiv National Automobile and Highway University, Associate Professor of the Department of Economics and Entrepreneurship, Kharkiv, Ukraine.

Грабар Дмитро Олександрович - студент, Харківський національний автомобільно-дорожній університет, м. Харків, Україна.

Грабарь Дмитрий - студент, Харьковский национальный автомобильнодорожный университет, г. Харьков, Украина.

Grabar Dmytro - student, Kharkiv National Automobile and Highway University, Kharkiv, Ukraine. 